\title{
Post-fire management and recovery of a pine forest in Greece
}

\author{
Ioannis Spanos, Yannis Raftoyannis, Panagiotis Platis and Eleni Xanthopoulou
}

Spanos, I. Raftoyannis, Y., Platis, P. and Xanthopoulou, E. 2010. Post-fire management and recovery of a pine forest in Greece. - Web Ecol. 10: 27-31.

\begin{abstract}
The effects of management after fire in Pinus halepensis forests were assessed in northern Greece. Seeding, logging and building of log barriers were applied in burned sites and compared to a control site. Two years after treatment application, 70-80\% of the ground in all sites was covered with vegetation. Seeding with herbaceous plants did not increase plant cover. Logging and building of $\log$ barriers negatively affected herbaceous species but increased woody species. During the first spring after fire, the highest numbers of $P$. halepensis seedlings were observed in the control site and the lowest number in the logged site. Logging and log barrier building had a negative effect on pine regeneration compared to control and seeding treatments. Woody plant composition was similar in control and seeding sites, with dominance of P. halepensis and Cistus species. A different pattern was observed in the logging and log-barrier sites with a low number of seeders and a high number of resprouter species.
\end{abstract}

I. Spanos (ispanos@fri.gr), P. Platis and E. Xanthopoulou, NAGREF, Forest Research Inst., GR-57006 Vassilika, Greece. - Y. Raftoyannis, TEI Lamias, Dept of Forestry, GR-36100 Karpenisi, Greece.

Wildfires often occur in Mediterranean forests that usually recover through natural regeneration (Trabaud 1994, Ne'eman 1997, Pausas et al. 1999, Leone et al. 2000). Among pines, Pinus halepensis Mill. is the species that has better adapted to regenerate after fire (Thanos et al. 1996, Tsitsoni 1997, Tsitsoni and Karagiannakidou 2000, Pausas et al. 2003).

After fire, soils are vulnerable to accelerated rates of soil erosion and can yield large but often variable amounts of sediment (DeBano et al. 1998). Post-fire rehabilitation treatments can be important in minimizing damage to soil, water and plant resources (Vallejo et al. 2000). Rehabilitation methods such as grass seeding, logging, building of branch barriers and mulching have been widely used, although little information is available (Robichaud et al. 2000). However, restoration activities such as tree felling (to create terraces with dead trees) and planting trees can be harmful if these actions are not implemented at the right time (Ubeda et al. 2006).
Although the effects of fire on Mediterranean pine ecosystems are well documented, few studies have focused on post-fire management activities and their effects on ecosystem recovery (Ne'eman et al. 1995, Zagas et al. 2004, Spanos et al. 2005, Raftoyannis and Spanos 2005, Spanos et al. 2010). In this study, we assessed the effects of postfire management practices on $P$. halepensis forest recovery in northern Greece.

\section{Material and methods}

The study area was located in the Kassandra peninsula, almost $100 \mathrm{~km}$ south of Thessaloniki, Greece (39 $57^{\prime} 92^{\prime \prime} \mathrm{N}$, $23^{\circ} 33^{\prime} 13^{\prime \prime E}$ ). Pinus halepensis forms uneven-aged stands at a density of 320 trees ha $^{-1}$, with a canopy height at 16 $\mathrm{m}$, mean diameter at breast height $21 \mathrm{~cm}$, wood volume $120 \mathrm{~m}^{3} \mathrm{ha}^{-1}$ and annual wood growth of $6.5 \mathrm{~m}^{3} \mathrm{ha}^{-1}$. The climate is Mediterranean with $550 \mathrm{~mm}$ mean annual rain- 
fall and $16.5^{\circ} \mathrm{C}$ mean annual air temperature. Rainfall is irregular, distributed mainly in spring and autumn, and the dry season lasts from May to September.

On 22 and 23 August 2006, a high-intensity crown fire burned more than 7000 ha of $P$. halepensis forest. Four months after the fire, four permanent plots 0.5 ha each $(100 \times 50 \mathrm{~m})$ were established on a slope $(30 \%)$ in the burned area. In the first plot (control), no action was taken. The second plot was sown with a mix of equal quantities of Dactyllis glomerata L., Lolium rigitum Guard. and Phalaris tuberosa L. var. aquatica seeds (seeding). In the third plot, all burned trees were logged and removed from the site using animal traction (logging). In the fourth plot, all burned trees were logged and log barriers were constructed along contour lines with a distance of $5 \mathrm{~m}$ between them (barriers). Soil sampling revealed no significant differences between the plots in $\mathrm{pH}$ (mean value $=7.1$ ), phosphorous content (mean value $=3.2 \mathrm{mg}$ per $100 \mathrm{~g}$ ) and organic matter content (mean value $=1.3 \%)$. As replicated plots were not available for the treatments, the extrapolation of results should be considered with precaution.

Groundcover, pine regeneration and woody plant cover were monitored on April 2007, October 2007, April 2008 and October 2008. In each plot, six permanent rectangular plots $(20 \times 3 \mathrm{~m})$ were established along contour lines. Ground cover was characterized every $10 \mathrm{~cm}$ along the two longer plot borders, using a metal pin vertical to the ground. Five cover categories were used: stones, bare soil, plant debris, herbaceous plants and woody plants. On the same dates and inside the strip plots, we recorded the number of viable pine seedlings and estimated the percentage of plant cover for each woody plant species.

Differences between treatments were tested with analysis of variance (ANOVA) and means were compared with Tukey's multiple comparison test. Percent data did not satisfy ANOVA assumptions and they were arcsine transformed prior to statistical analysis, but actual percentages are given in the tables. All tests for significance were conducted at the $\mathrm{p} \leq 0.05$ level.

\section{Results}

Eight months after fire, significantly higher rates of exposed soil were found in logged and log-barrier plots ( $\mathrm{Ta}$ ble 1). Regeneration of herbaceous species seemed to be

Table 1. Percentage of ground cover in each treatment. Means within the same ground cover type and date of observation, followed by the same letter are not significantly different at $\mathrm{p} \leq 0.05(\mathrm{n}=12)$.

\begin{tabular}{|c|c|c|c|c|c|c|}
\hline \multirow[b]{2}{*}{ Date } & \multirow[b]{2}{*}{ Treatment } & \multicolumn{5}{|c|}{ Ground cover (\%) } \\
\hline & & Stones & Bare soil & Plant debris & Herbaceous plants & Woody plants \\
\hline \multirow[t]{4}{*}{ Apr 2007} & Control & $4^{a}$ & $22^{a}$ & $3^{a}$ & $67^{c}$ & $4^{a}$ \\
\hline & Seeding & $2^{a}$ & $16^{\mathrm{a}}$ & $3^{a}$ & $68^{\mathrm{c}}$ & $11^{\mathrm{b}}$ \\
\hline & Logging & $7^{\mathrm{b}}$ & $44^{\mathrm{c}}$ & $14^{\mathrm{b}}$ & $17^{a}$ & $18^{\mathrm{b}}$ \\
\hline & Barriers & $1^{\mathrm{a}}$ & $32^{\mathrm{b}}$ & $16^{\mathrm{b}}$ & $33^{\mathrm{b}}$ & $17^{\mathrm{b}}$ \\
\hline \multirow[t]{4}{*}{ Oct 2007} & Control & $1^{\mathrm{a}}$ & $12^{a}$ & $1^{\mathrm{a}}$ & $72 \mathrm{~d}$ & $15^{\mathrm{a}}$ \\
\hline & Seeding & $3^{a}$ & $14^{\mathrm{a}}$ & $3^{a}$ & $62 c$ & $18^{\mathrm{a}}$ \\
\hline & Logging & $7^{b}$ & $28^{\mathrm{b}}$ & $11^{\mathrm{b}}$ & $20 \mathrm{a}$ & $35^{b}$ \\
\hline & Barriers & $1^{\mathrm{a}}$ & $17^{\mathrm{a}}$ & $13^{\mathrm{b}}$ & $37^{\mathrm{b}}$ & $32^{\mathrm{b}}$ \\
\hline \multirow[t]{4}{*}{ Apr 2008} & Control & $3^{\mathrm{a}}$ & $10^{\mathrm{a}}$ & $2^{a}$ & $65^{\mathrm{c}}$ & $11^{a}$ \\
\hline & Seeding & $2^{a}$ & $8^{a}$ & $7^{\mathrm{b}}$ & $59^{\mathrm{c}}$ & $25^{\mathrm{b}}$ \\
\hline & Logging & $5^{b}$ & $16^{\mathrm{b}}$ & $11^{\mathrm{c}}$ & $36^{a}$ & $32^{\mathrm{bc}}$ \\
\hline & Barriers & $1^{\mathrm{a}}$ & $8^{a}$ & $9^{b}$ & $43^{b}$ & $39^{\mathrm{c}}$ \\
\hline \multirow[t]{4}{*}{ Oct 2008} & Control & $3^{a}$ & $11^{a}$ & $5^{a}$ & $52^{\mathrm{c}}$ & $30^{a}$ \\
\hline & Seeding & $2^{a}$ & $13^{a}$ & $13^{\mathrm{c}}$ & $41^{\mathrm{b}}$ & $32^{a}$ \\
\hline & Logging & $5^{b}$ & $12^{a}$ & $8^{\mathrm{b}}$ & $36^{a}$ & $39^{\mathrm{b}}$ \\
\hline & Barriers & $1^{\text {a }}$ & $12^{a}$ & $10^{\mathrm{b}}$ & $34^{a}$ & $43^{b}$ \\
\hline
\end{tabular}


inhibited by logging and the building of log barriers. On the other hand, woody plant regeneration was better in all manipulated plots compared to control plots. In October 2007, the percentage of ground covered by woody plants almost doubled compared to April previous year, and this change was particularly evident in the logged and logbarrier sites. At the same time, significantly higher rates of bare soil were still evident in the logged plot. In April 2008 , a further reduction on the percentage of bare soil was recorded, mainly in the logged and log-barrier sites. In October $2008,70-80 \%$ of the ground in all treatments was covered by plants and the percentage of exposed soil was similar in all treatments. Seeding with herbaceous plants did not increase vegetation cover. Logging and building of $\log$ barriers seemed to negatively affect herbaceous species, but increased the regeneration of woody species.

During the first spring after the fire, the highest number of $P$. halepensis seedlings was observed in the control plot and the lowest number in the logged plot (Table 2). A high rate of seedling mortality during summer time almost halved the number of viable seedlings in October 2007. Additional germination of pine seeds increased the number of seedlings by April 2008, and the highest seedling density was observed again in the control plot. By October 2008, the number of pine seedlings increased in all treatments. Logging and log barrier building had a negative effect on pine regeneration compared to control and seeding treatments.

In April 2007, $P$. halepensis was the dominant woody species, followed by Asparagus acutifolius L. in control, seeding and barrier treatments. The logged site was dominated by Smilax aspera L. (Fig. 1). Cistus monspeliensis L., Cistus salvifolius L. and Cistus incanus L., were the dominant woody species in 2008 although Pistacia lentiscus L., Phillyrea latifolia L., Quercus coccifera L. and Spartium junceum L. were present in most treatments. In October 2008, woody plant composition was similar in control and seeding sites, with a dominance of $P$. halepensis and Cistus species. A different pattern was observed in the logging and $\log$ barrier plots which showed lower numbers of $P$. halepensis and Cistus species, but higher numbers of $P$. latifolia, P. lentiscus and S. aspera individuals.

\section{Discussion}

In our study, post-fire treatments did not significantly affect ground cover or species composition. Logging and the building of barriers with logs negatively affected herbaceous species, but increased the regeneration of woody species, while seeding with herbaceous plants did not increase overall cover. Reports from similar studies show that post-fire logging increase sediment transfer (Helvey et al. 1985), but logging residues can protect the disturbed soils from rainfall impact and reduce soil loss up to $95 \%$ (Shakesby et al. 1996). The main reason could be the use of ground-based logging equipment which can cause disturbance and soil compaction (Beschta et al. 2004) and reduce plant growth on trails (Smith and Wass 1980). The building of log and branch barriers had no positive effect on ground cover as shown elsewhere (Raftoyannis and Spanos 2005).

Post-fire management can therefore affect plant regeneration, and thus, alter plant community structure. In our site, control and seeding treatments were dominated by seeders while the logging and log-barrier treatments were dominated by resprouters. Resprouting species seem to be more resistant to post-fire activities as has also been observed by Stuart et al. (1993). Post-fire logging can encourage colonization of several native ruderal species (Abrahamson 1984, Greenberg et al. 1994). Cutting down burned trees, removing twigs or leaving them in the burned area had only a marginal influence on total species richness or cover of resprouting species (Ne'eman et al. 1995). Removal of burned Pinus pinaster trees, one year after fire, had a minimal effect on vegetation structure, and only legumes increased in logged sites (Perez and Moreno 1998).

In our study area $P$. halepensis is the dominant tree species and its regeneration success after fire is crucial for ecosystem health and recovery (Tsitsoni 1997). Two years after the Kassandra fire, the highest number of $P$. halepensis seedlings was observed in the control plot, followed by the seeding treatment, while logging and log-barrier building had a negative effect on pine regeneration. These negative effects has also been reported elsewhere (Ne'eman et

Table 2. Mean number of $P$. halepensis seedlings per square meter in each treatment. Means within the same date of observation, followed by the same letter are not significantly different at $\mathrm{p} \leq 0.05(\mathrm{n}=6)$.

\begin{tabular}{lcccc}
\hline & \multicolumn{3}{c}{ Treatment } \\
\cline { 2 - 5 } Date & Control & Seeding & Logging & Barriers \\
\hline Apr 2007 & $7.3^{\mathrm{c}}$ & $4.7^{\mathrm{b}}$ & $1.2^{\mathrm{a}}$ & $3.3^{\mathrm{b}}$ \\
Oct 2007 & $2.1^{\mathrm{b}}$ & $2.3^{\mathrm{b}}$ & $0.5^{\mathrm{a}}$ & $1.5^{\mathrm{a}}$ \\
Apr 2008 & $3.2^{\mathrm{b}}$ & $2.3^{\mathrm{a}}$ & $1.2^{\mathrm{a}}$ & $2.3^{\mathrm{a}}$ \\
Oct 2008 & $3.8^{\mathrm{b}}$ & $3.0^{\mathrm{b}}$ & $1.5^{\mathrm{a}}$ & $2.4^{\mathrm{a}}$ \\
\hline
\end{tabular}




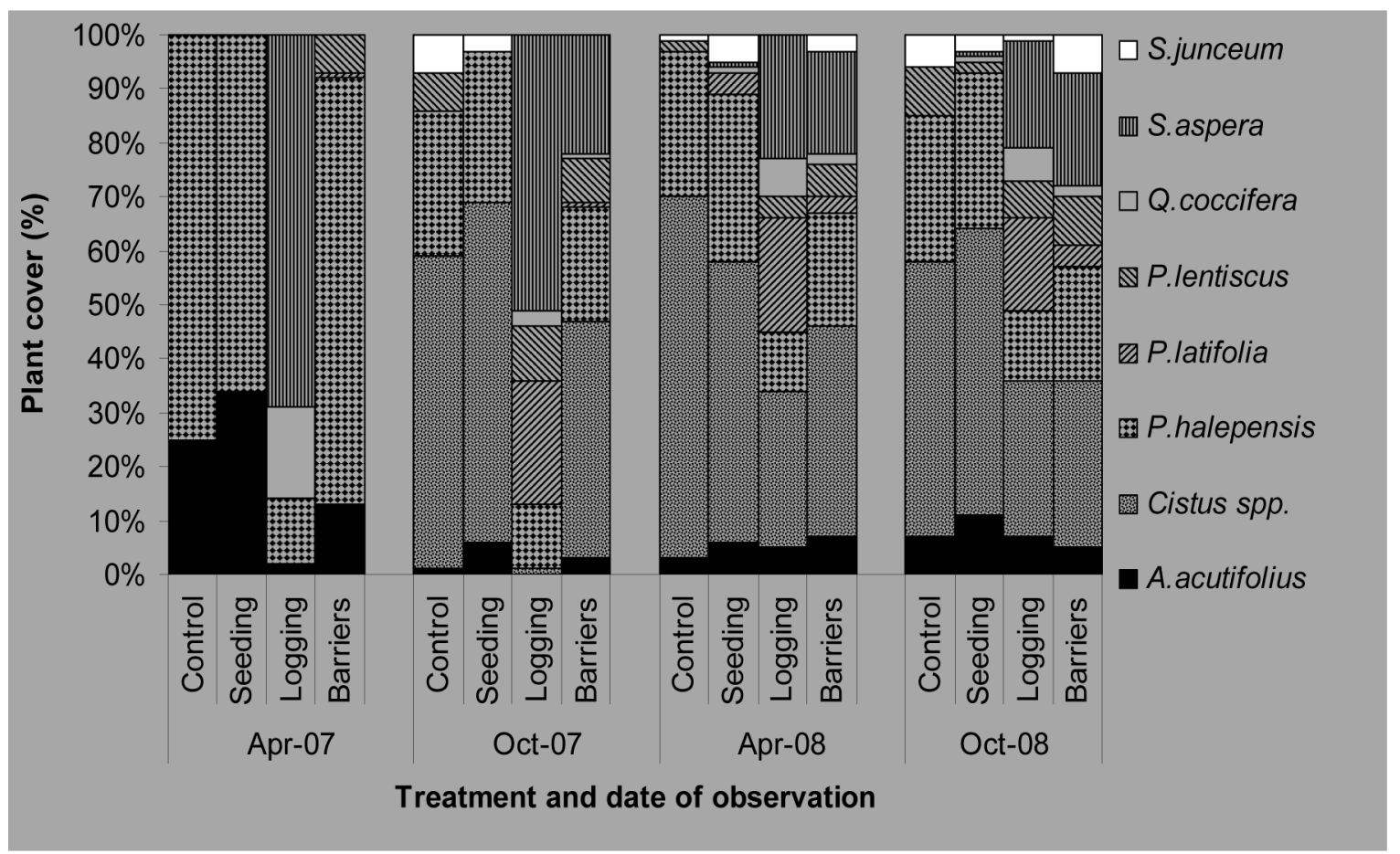

Figure 1. Percentage of ground cover by woody species.

al. 1993, Saracino and Leone 1993, Spanos et al. 2005) although in a similar study, removal of burned trees had no effect on pine recruitment (Ne'eman 1997). MartinezSanchez et al. (1999) concluded that traditional wood removal practices do not threaten natural post-fire $P$. halepensis re-establishment if initial seedling density is large enough. The timing of felling after fire has a significant effect on seedling survival, and in our case, logging occurred at the start of seedling emergence. Should logging have occurred after seedling emergence, a high number of seedlings could have been killed, thus threatening post-fire recovery. It is therefore advisable that logging after fire is carried out well before seedling emergence.

Acknowledgements - The authors thank the European Commission and the Greek General Secretariat for Research and Technology and NAGREF (National Agricultural Research Foundation for providing funds to conduct this research. Additionally, many thanks to Evagelos Havales (forester) and Theologis Palatzidis (technician) for their help in the field and laboratory.

\section{References}

Abrahamson, W. G. 1984. Species responses to fire on Florida Lake Wales Ridge. - Am. J. Bot. 71: 35-43.

Beschta, R. L. et al. 2004. Post-fire management of forested public lands of the western United States. - Conserv. Biol. 18: 957-967.
De Bano, L. F. et al. 1998. Fire effects on ecosystems. - John Wiley and Sons.

Greenberg, C. H. et al. 1994. Effect of high-intensity wildfire and silvicultural treatments on reptile communities in sandpine scrub. - Conserv. Biol. 8: 1047-1057.

Helvey, J. D. et al. 1985. Plant nutrient losses by soil erosion and mass movement after wildfire. - J. Soil Water Conserv. 40: $168-173$.

Leone, V. et al. 2000. Ecology of post-fire recovery in Pinus halepensis in southern Italy. - In: Trabaud, L. (ed.), Life and environment in the Mediterranean. Wit Press, pp. 129-154.

Martínez-Sánchez, J. J. et al. 1999. Effect of burnt wood removal on the natural regeneration of Pinus halepensis after fire in a pine forest in Tus valley (southeast Spain). - Forest Ecol. Manage. 123: 1-10.

Ne'eman, G. 1997. Regeneration of natural pine forest - review of the work done after the 1989 fire in Mount Carmel, Israel. - Int. J. Wildl. Fire 7: 295-306.

Ne'eman, G. et al. 1993. The resilience of vegetation to fire in an east Mediterranean pine forest on Mount Carmel, Israel: the effects of post-fire management. - In: Trabaud, L. and Prodon, R. (eds), Fire in Mediterranean ecosystems. Commission of the European Communities, pp. 127-141.

Ne'eman, G. et al. 1995. Recovery of vegetation in a natural east Mediterranen pine forest on Mount Carmel, Israel as affected by management strategies. - Forest Ecol. Manage. 75: $17-26$.

Pausas, J. G. et al. 1999. Post-fire regeneration patterns in the eastern Iberial Peninsula. - Acta Oecol. 20: 499-508. 
Pausas, J. G. et al. 2003. Fire severity and seedling establishment in Pinus halepensis woodlands, eastern Iberial Peninsula. Plant Ecol. 169: 205-213.

Perez, B. and Moreno, J. M. 1998. Fire-type and forestry management effects on the early post-fire vegetation dynamics of a Pinus pinaster woodland. - Plant Ecol. 134: 27-41.

Raftoyannis, Y. and Spanos, I. 2005. Evaluation of log and branch barriers as post-fire rehabilitation treatments in a Mediterranean forest in Greece. - Int. J. Wildl. Fire 14: 183-188.

Robichaud, P. R. et al. 2000. Evaluating the effectiveness of postfire rehabilitation treatments. Rocky Mountain Research Station general technical report RMRS-GTR-63. - USDA Forest Service Fort Collins, CO.

Saracino, A. and Leone, V. 1993. Natural regeneration 2 and 4 years after fire of Pinus halepensis Miller in dunal environment. - In: Trabaud, L. and Prodon, R. (eds), Fire in Mediterranean ecosystems. Commission of the European Communities, pp. 141-150.

Shakesby, R. A. et al. 1996. Limiting the soil degradational impacts of wildfire in pine and eucalyptus forests in Portugal: a comparison of alternative post-fire management practices. - Appl. Geogr. 16: 337-355.

Smith, R. B. and Wass, E. F. 1980. Tree growth on skid roads on steep slopes logged after wildfires in central and southeastern British Columbia. - Canadian Forestry Service, Pacific Forest Research Centre.

Spanos, I. et al. 2005. Post-fire management activities and their effects on Pinus halepensis Mill. forests in northern Greece. Plant Soil 278: 171-179.

Spanos, I. et al. 2010. Evaluation of post-fire restoration in suburban forest of Thessaloniki, northern Greece. - Global Nest in press.
Stuart, J. D. et al. 1993. Early successional pathways following wildfire and subsequent silvicultural treatment in Douglasfir/hardwood forests, northwestern California. - Forest Sci. 39: 561-572.

Thanos, C. A. et al. 1996. Early post-fire regeneration of a Pinus halepensis forest on Mount Parnis, Greece. - J. Veg. Sci. 7: 273-280.

Trabaud, L. 1994. Post-fire plant community dynamics in the Mediterranean basin. - In: Moreno, J. M. and Oechel, C. (eds), The role of fire in Mediterranean-type ecosystems. Springer, pp. 1-15.

Tsitsoni, T. 1997. Conditions determining natural regeneration after wildfires in the Pinus halepensis (Miller 1768) forests of Kassandra Peninsula (north Greece). - For. Ecol. Manage. 92: 199-208.

Tsitsoni, T. and Karagiannakidou, V. 2000. Site quality and stand structure in Pinus halepensis forests of north Greece. - Forestry 73: 51-64.

Ubeda, X. et al. 2006. Vegetation regrowth after differential intensity forest fire in a Mediterranean environment, northern Spain. - Land Degrad. Dev. 17: 429-440.

Vallejo, R. et al. 2000. Reclamation of Mediterranean ecosystems affected by wildfires: forest management recommendations. - In: Balabanis, P. et al. (eds), Mediterranean desertification. Research results and policy implications. European Commission, pp. 407-416.

Zagas, T. et al. 2004. Post-fire regeneration of Pinus halepensis Mill. stands in the Sithonia peninsula, northern Greece. Plant Ecol. 171: 91-99. 